\title{
Transforming waste vegetable oils to biodiesel, establishing of a waste oil management system in Albania
}

\author{
Dritan Topi ${ }^{1}$ (D)
}

Received: 27 December 2019 / Accepted: 17 February 2020 / Published online: 2 March 2020

(c) Springer Nature Switzerland AG 2020

\begin{abstract}
Nowadays, food wastes contribute to a significant part of the total world wastes' data, having a direct impact on the environment and economic losses. Use of Vegetable Oils for frying and other food-chain services studied for their potential as a feedstock source for biodiesel production. Development of the processing technologies has exploited their use as a valuable economic resource despite their status as food by-products. Recently in Albania, a private enterprise has oriented the investments in the frying waste vegetable oils by establishing a collecting network and their use for biodiesel production. In the first phase, is established the management system and collection network of Waste Vegetable Oil in restaurants, catering, and Fast-food chain in the Tirana-Durrësi region. The results during the first year have shown that the collected amount reached 400 tons. Waste Vegetable oil collected data have reached approx $100 \mathrm{t}$ per month. On a five-year strategic plan, the company aims to reach a collection of $15-20 \%$ of total waste vegetable oils, generated in-country, or potentially 6000-8000 tons per year. The contracts are organized bilaterally, between the end-point user and the company. Legislative enforcement to ban their disposal to the sewage system, or surface waters, are in action. Plant pilot experiments have successfully produced biodiesel using waste vegetable oils.
\end{abstract}

\section{Graphic abstract}

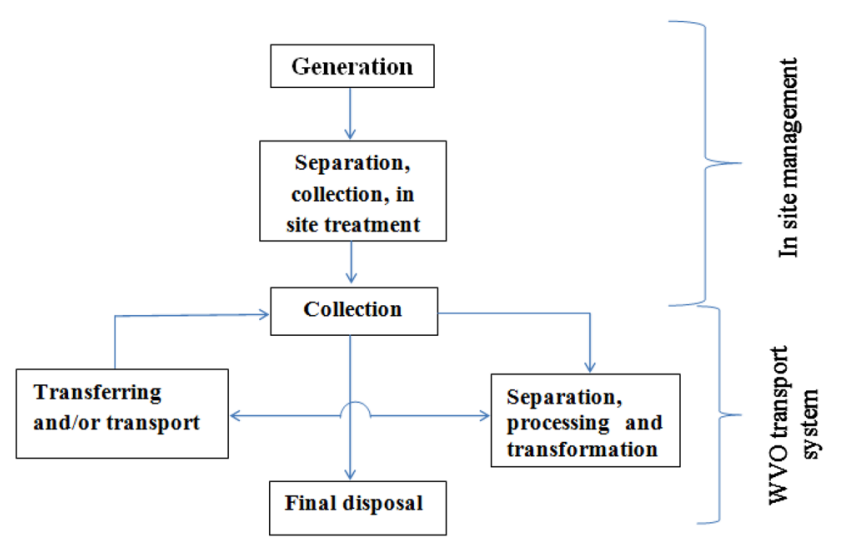

Keywords Waste management · Frying oils · Biodiesel · Environmental pollution · Albania

Dritan Topi, dritan.topi@unitir.edu.al | 'Department of Chemistry, Faculty of Natural Sciences, University of Tirana, Blvd. Zogu 1, No. 25/A, 1000 Tirana, Albania. 


\section{Introduction}

Food wastes contribute to a significant part of the total global wastes produced by having a direct impact on the environment. Indirectly, their generation does increase net economic costs of food production, use of freshwater, higher levels o fossil fuel consumption, an increase of gas emissions [15]. Waste Vegetable Oils (WVO) generated in restaurants, caterings, and fast-food chains are one of the main groups of food wastes. Until recently, most WVO used to support fuel in different energyconsuming processes. In many industrialized countries is settled a collection infrastructure [17]. There are in operation efficient Waste Oil Management Systems supported by government bodies through financial support and legislation [20]. The WVO amounts vary in different countries according to the economic developing status. So, Hill [17] has estimated that in the USA, exists a potential of hidden biodiesel production over 100 million gallons per year.

The use of vegetable oils, especially palm oil, as a source of diesel fuel, was first mentioned by Rudolf diesel in its early studies at the beginning of the XXth century. Latter, their study can be found in the literature review throughout the $1940 \mathrm{~s}$, and linked with the theme of energy independence to the European Colonies, especially in Africa [22]. The attempts to produce the First 'Biodiesel' performed in the former colony of Belgian Congo in the $1930 \mathrm{~s}$. In contrast, the first report on the product known as biodiesel belongs to the Belgian patent 422,877, granted on August 31, 1937, to Chavane [22]. According to the American Society for Testing and Materials, biodiesel is a mixture of Fatty Acid Monoalkyl Esters (FAME) derived from lipid feedstock, such as vegetable oil or animal fat [4]. Primary sources of vegetable oils are oilseed crops such as rapeseed, soybean or palm oil $[2,24,27,28]$. Biodiesel production is not feasible due to its high-cost production compared to fossil fuels. Waste Vegetable Oils sourced from restaurants, Fast-food chain, chip shops, industrial food producers constitute a source of interest for biodiesel production $[6,8,13,31$, $35]$. Vegetable oils used in an in-depth frying process for a period that fulfills the chemical parameters concerning the food safety regulations [18]. Waste frying oils are a mixture of triglycerides constituted by saturated and unsaturated fatty acid chains [34].

This feedstock category is an alternative source of biovegetable oils and shows interest due to the low price compared to raw bio-oils [3, 35]. Biodiesel is a mixture of Fatty Acid Methyl Esters (FAME) and may replace fossil fuel. Together with bioethanol are classified as biofuels, and it is thoroughly and quickly biodegradable [9]. The process used to convert vegetable oils to biodiesel is called transesterification, where a natural oil triglyceride, constituted of animal fats or vegetable oils, reacts with a short-chain alcohol, methanol or ethanol, in the presence of a catalyst to produce fatty acid alkyl esters $[7,27]$.

In recent times a global problem has been raised relating to use arable lands for oilseed crops with destination to biodiesel production. That directly has contributed to the increase in food prices globally. To reduce the pressure, the use of the WVO for the production of biodiesel is one alternative. Different publications have proposed that the production of biodiesel from virgin oils has more significant costs compared to waste frying oils and animal fats $[9,10,25]$. In 2011, according to European Biodiesel Board were produced about 8.6 million metric tons, with an installed capacity of 23.5 million tons of production, and Germany was the biggest producer accounting for $32 \%$ of the total production [11].

There is considerable data on the adverse health and environmental impact of the WVO. Smoking point temperatures induce various chemical and physical deterioration processes. Oxidation and polymerization reactions catalyze, leading to numerous volatile and nonvolatile possible carcinogenic by-products [30]. The acrolein toxicity is well documented, due to its ability to crosslink proteins and bind covalently to nucleic acids, acting as a potent carcinogenic factor for oral, respiratory, and bladder cancer in humans and other species. Dumping of Aqueous-Cooking Oils to the sewage system gives implications on the ecosystem. Mutagenic and genotoxic effects are investigated in such conditions $[18,19]$.

One of the primary outcomes from implementing the Waste management System on WVO to biodiesel production is linking to environmental benefits, which results in diminishing the number of effluents to the urban wastewaters. It brings a reduction of the urban wastewaters treatment costs. Life Cycle Analysis of biodiesel production has shown that it contributes minimally to global warming. Due to their origin from vegetative sources, it serves as a sink to $\mathrm{CO}_{2}[25,28]$.

There is a reduction in the $\mathrm{CO}_{2}$ emissions compared to conventional fuel, also reduction to PM10 and Hydrocarbons $(\mathrm{HC})$, while the NOx emissions are increased compared to conventional fuel. There is a correlation between the percent biodiesel in blended fuel and reduction of gas emissions $(\mathrm{CO}, \mathrm{PM}, \mathrm{HC})$ and the increase of $\mathrm{NOx}$ emissions $[14,16]$ (Fig. 1). 
Fig. 1 Transesterification of triglycerides with $\mathrm{MeOH}$ to Fatty Acids Methyl Esters in the presence of catalysts [32]<smiles>[R]C(=O)OCC(COC([R])=O)OC([R])=O</smiles>

Methanol<smiles></smiles>

Fatty Acid Methyl Esters (Biodiesel)

Glycerine

\subsection{Chemistry of biodiesel}

Biodiesel production comprises the process of transesterification where a triglyceride reacts with an alcohol to form esters and glycerol. The reaction takes place in the presence of a catalyst, usually a strong alkaline like sodium hydroxide. Through the process of transesterification, the viscosity of biodiesel is reduced compared to raw vegetable oil. This process reduces the viscosity of vegetable oils without affecting the heating value of biofuel. In the process of transesterification are used alcohols with 1-4 C atoms, while nomenclature of the esters based according to the employed alcohol [27, 31, 32].

Generally, the catalyst is classified in acidic and alkaline catalysts. Sulphuric and hydrochloric acids are the most preferred acidic catalyst, while the sodium hydroxide potassium hydroxide, sodium methoxide are used as Basic catalysts [27, 31, 32].

The transesterification of vegetable oil with alkaline catalysts is susceptible to the presence of water and free fatty acids by slowing the reaction. An amount of
$0.1 \% \mathrm{H}_{2} \mathrm{O}$ in the medium will decrease significantly the amount of ester formed in the process [7, 32].

\subsection{Experimental section}

Collection of Waste Vegetable Oils by the Fast-Food and Restaurant chains in the Tirana area accomplished. Fresh vegetable oils used to produce biodiesel, which used for physical parameter comparison, were purchased from the local market. Other chemicals Methanol (99.9\%), $\mathrm{NaOH}, \mathrm{H}_{2} \mathrm{SO}_{4} \mathrm{CC}$, and Iso-propanol, were purchased by Sigma-Aldrich. Figure 2 is presented the production diagram of the biodiesel from WVO, according to the Canakci and Van Gerpen [7]. Biodiesel produced from waste vegetable oils and fresh vegetable oils synthesized in the pilot-scale by using alkaline, $\mathrm{NaOH}$ as a catalyst. The ester preparation involves a two-step transesterification reaction following and drying [24, 31]. The two-step reaction processed in a $100 \%$ methanol medium or molar ratio of methanol-to-oil of $6: 1$. With methanol equally divided into the two steps. Lab-scale
Fig. 2 General Scheme of WVO and FVO to produce biodiesel [7]

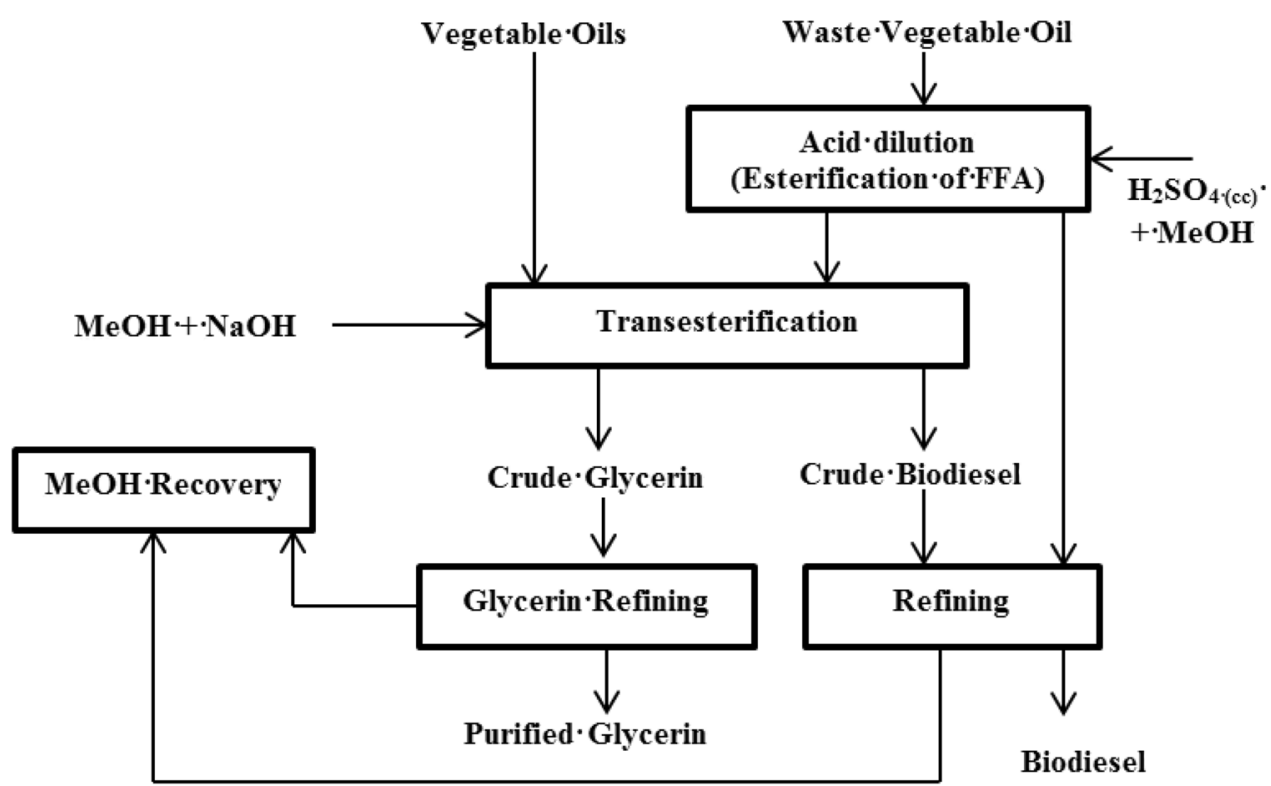

SN Applied Sciences A SPRINGER NATURE journa 
reaction, $200 \mathrm{~g}$ of oil placed in a dry flask equipped with a magnetic stirrer and thermometer. Dried conditions are essential as water presence will consume the catalyst by impacting the reaction speed of transesterification. In another flask, approximately $23 \mathrm{~g}$ of methanol mixed with $1.0 \mathrm{~g}$ of $\mathrm{NaOH}$ ( $0.5 \%$ by the weight of oil). The mixture was prepared by adding the catalyst solution to the oil flask and was stirred vigorously for $20 \mathrm{~min}$ at $55^{\circ} \mathrm{C}$. After the reaction, the mixture left in a separation funnel for the separation of glycerol by the Fatty acid methyl esters (FAME) mixture. The top crude ester layer was separated and washed with distilled water to remove the catalyst and methanol until it became utterly translucent. Finally, the FAME mixture dried with anhydrous sodium sulfate.

\subsection{Transesterification}

Feedstock volume consisting of high acidic values primarily were processed to a pre-treatment stage to eliminate the Free Fatty Acids (FFA) present in the medium under a $1 \%$ level. The treatment procedure accomplished by treating the feedstock volume and $\mathrm{H}_{2} \mathrm{SO}_{4}$ and methanol, according to Zhang et al. [35]. Figure 2 is a production scheme of biodiesel in the laboratory.

\section{Results and discussion}

\subsection{Waste vegetable oils}

The amount of waste vegetable oils produced by the restaurants and fast-food chains is not comfortable to evaluate, but considerations on comparative data are published. This study accomplished in 2017. According to the study published by Wiltsee [33], the mean value of WVO produced resulted in $8.87 \mathrm{lb} / \mathrm{y}$ person of yellow grease and $13.37 \mathrm{lb} / \mathrm{y}$ person of trap grease. Referring to the values presented in the study, we assume that WVO produced in Tirana known as the densest Metropolitan area in Albania. Data predictions based on the proposed coefficients by Wiltsee [33]. In this study, we have calculated that the potential of production by the restaurant and fastfood chain in Tirana goes to approximately $6000 \mathrm{t}$ WVO (Table 1). While the statistics on the number of restaurants and Fast-foods delivered by the public body "National Authority of Food' [1].

The cost of WVO collected by the restaurants and fastfoods evaluated in the interval $0.30-0.35 €$ per liter, in correlation with the WVO produced by the restaurant or the Fast-food producers. The overall cost increased significantly to $0.60 € / /$, including the transporting cost.
Table 1 Data on Restaurants and Fast-Foods in Tirana City, inhabitants, and assumptions on grease production

\begin{tabular}{ll}
\hline Subject of evaluation & Data \\
\hline Number of restaurants & 867 \\
Population & 622,202 \\
Yellow Grease & $2503328^{\mathrm{a}, \mathrm{b}}$ \\
Trap Grease & $3773359^{\mathrm{a}, \mathrm{b}}$ \\
Total Grease & $6276687^{\mathrm{a}, \mathrm{b}}$ \\
Restaurant/ 1000 persons & $\sim 1.4$ \\
Yellow Grease & $4.02^{\mathrm{a}}$ \\
Trap Grease & $6.06^{\mathrm{a}}$ \\
\hline
\end{tabular}

aalues in $\mathrm{kg}$

${ }^{\mathrm{b}}$ Data generated according to [33]

The physical and chemical parameters of the WVO vary according to their exposure time, temperature, and commodity. During that time, several chemical reactions take place, such as hydrolysis, oxidation, and polymerization. From the hydrolysis of triglycerides, the percentage of free fatty acids increased; polymerization reaction increases the viscosity of the WVO, while the oxidation reaction increases the color opacity [6]. Chemical composition is different, and not easy to identify due to the variety of Vegetable oils or hydrogenated vegetable oils used by operators. Lipids, vegetable oils, and greases, used in the frying process and other food technology processes, produce wastes of vegetable oils. During heating, the WVO mixture exposed to other agents $\left(\mathrm{H}_{2} \mathrm{O}\right.$, sugars, proteins, and $\mathrm{O}_{2}$ ) by influencing the characteristics, such as viscosity, acidity, humidity, and color. According to the Free Fatty Acid (FFA) content, they are classified in yellow grease with acidity up to $15 \%$ FFA, and brown grease with FFA level above this value [8].

In practice, the conversion process of WVO to biodiesel through the alkaline catalyst usually is challenging to apply. The presence of water content and large amounts of free fatty acids will deactivate the catalyst. In such conditions, the catalyst will spend and produce soap, fatty acid salts of sodium or potassium kations $[2$, $7,21,31]$. The application of transesterification through the alkaline catalyst needs low levels of free fatty acids to be present on feedstock. Published results indicate that acidic catalysts must decrease the level of FFA to less than $2 \%$ before the application of chemical reaction under the alkaline catalysts, which finally will give satisfactory results [13]. Figure 2 presents the collection flowchart implied by the operator. The collection process starts from the generating site, where the collector has agreed with the WVO producer to separate it in plastic cans with a bottom faucet, that enable water separation in the site. Collection to the site is organized periodically for all the urban areas of 
Table 2 Specifications for biodiesel fuel (B100) blend stock for distillate fuels (ASTM D-6751-03) [4]

\begin{tabular}{|c|c|c|c|}
\hline Property & ASTM method & Limits & Units \\
\hline Flashpoint (closed cup) & D 93 & $130.0 \mathrm{~min}$ & ${ }^{\circ} \mathrm{C}$ \\
\hline Water and sediment & D 2709 & $0.050 \max$ & Vol\% \\
\hline Kinematic viscosity, $40^{\circ} \mathrm{C}$ & D 445 & $1.9-6.0$ & $\mathrm{~mm}^{2} \mathrm{~s}^{-1}$ \\
\hline Sulfated ash & D 874 & $0.020 \max$ & mass $\%$ \\
\hline Sulphur & D 5453 & $0.05 \max$ & mass $\%$ \\
\hline Copper strip corrosion & D 130 & No. 3 max & - \\
\hline Cetane number & D 613 & $47 \mathrm{~min}$ & - \\
\hline Cloud point & D 2500 & Report & ${ }^{\circ} \mathrm{C}$ \\
\hline $\begin{array}{l}\text { Carbon residue, } 100 \% \\
\text { sample }\end{array}$ & D 4530 & $0.050 \max$ & mass $\%$ \\
\hline Acid number & D 664 & $0.80 \max$ & $\mathrm{mg} \mathrm{KOH} \mathrm{g}^{-1}$ \\
\hline Free glycerine & D 6584 & $0.020 \max$ & mass $\%$ \\
\hline Total glycerine & D 6584 & $0.240 \max$ & mass $\%$ \\
\hline Phosphorous content & d 4951 & $0.001 \max$ & mass $\%$ \\
\hline $\begin{array}{l}\text { Distillation temperature, } \\
\text { Atmospheric equivalent }\end{array}$ & d 1160 & $360 \max$ & ${ }^{\circ} \mathrm{C}$ \\
\hline $\begin{array}{l}\text { Temperature, 90\% } \\
\text { recovered }\end{array}$ & & & \\
\hline
\end{tabular}

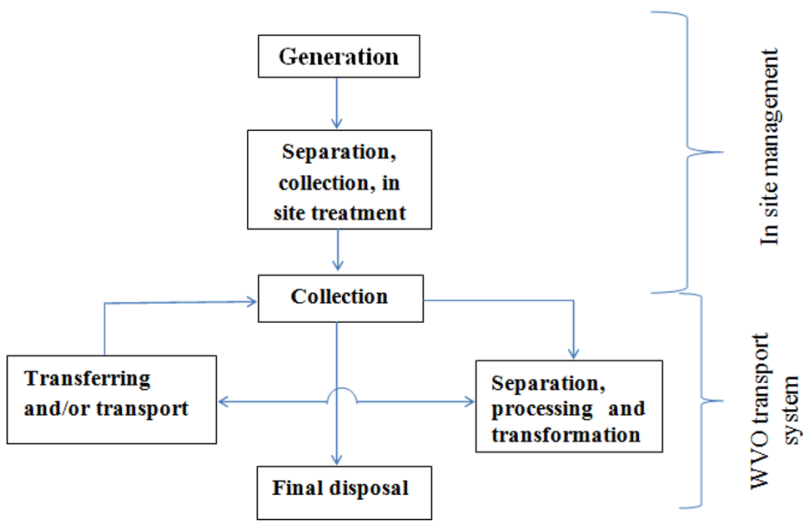

Fig. 3 Waste Vegetable oil Management System established by the operator

Tirana and Durresi based on a computing map aiming to diminish the transporting costs.

The properties of biodiesel vary depending on the oil feedstock and alcohol type. The biodiesel characteristics are always close to diesel fuel [21,29]. Biodiesel must meet the specification designated in ASTM D-6751, and presented in Tables 1, 2 before going to market (Fig. 3).

\subsection{Quality properties biodiesel}

Alternative fuels from both spark ignition (SI) and compression ignition $(\mathrm{Cl})$ engines have become very important owing to increased environmental protection concern, and need to reduce dependency on petroleum. In that group, the most used are natural gas, liquefied petroleum gas (LPG), and biofuel group that comprises transesterified vegetable oils and alcohols [23]. To be considered a car fuel or an extender for car fuels, FAME has to meet requirements imposed by national or international standards. EN 14124 gives the requirement that FAME has to fulfill before to go in distribution [12]. Different factors have indicated that the use of biodiesel (100\%), as fuel, is not recommended. Low melting temperatures and biological stability for long periods are two main condition factors. Another important factor is its water sensitivity; in contact with air, the humidity will initiate the hydrolysis reaction to FFA and methanol. Oxidation of biodiesel is a complex process that involves several mechanisms producing an array of chemical components such as aldehydes, acids, ketones, and oligomeric compounds. A variety of factors affect the level of decomposition products, as well as the rate of formation and decay reactions. These factors include the temperature, presence of light, catalytic metals in the fuel system, sump oil, or storage containers, type of biodiesel, fatty acid profile, blend level, other contaminants, and presence of antioxidants [5]. The different blending of biodiesel/diesel is under application, but it recommends that biodiesel could blend with fuel up to 20 percent $[4,26]$.

Engler distillation of $100 \mathrm{ml}$ biodiesel produced by Fresh Palm Oil/Waste Palm Oil (50:50) resulted in a final volume of distillate $95.0 \mathrm{ml}$ and residue $5.0 \mathrm{ml}$. The biodiesel density in temperature resulted in $\mathrm{d}=0.861 \mathrm{~g} \mathrm{ml}^{-1}$, in-room temperature $27^{\circ} \mathrm{C}$, while the Flashpoint $108^{\circ} \mathrm{C}$ (Table 3). The distillation interval $325-352{ }^{\circ} \mathrm{C}$ indicates a mixture of FAMEs.

A comparison of the maximum temperature values with the standard indicates the quality of the final product. The density of the final product is following EN14124 standards (Table 4).

Distillation of $100 \mathrm{ml}$ biodiesel produced from Waste Palm Oil (100\%) resulted in a volume of distillate $92.0 \mathrm{ml}$ and residue $8.0 \mathrm{ml}$. Density $=0.862 \mathrm{~g} \mathrm{ml}^{-1}$ in room temperature $27^{\circ} \mathrm{C}$ and Flashpoint $101^{\circ} \mathrm{C}$. In the second experiment, the evaluation of quality parameters shows that the product is following the standard.
Table 3 Engler distillation of biodiesel produced by Fresh Palm Oil/Waste Palm Oil (50:50)

\begin{tabular}{llllllllllll}
\hline Temperature $\left({ }^{\circ} \mathrm{C}\right)$ & 80 & 325 & 330 & 331 & 332 & 335 & 338 & 340 & 342 & 348 & 352 \\
\hline Volume $(\mathrm{ml})$ & 0 & 10 & 20 & 30 & 40 & 50 & 60 & 70 & 80 & 90 & 95 \\
\hline
\end{tabular}


Table 4 Engler distillation of biodiesel produced by waste palm oil (100\%)

\begin{tabular}{llllllllllll}
\hline Temperature $\left({ }^{\circ} \mathrm{C}\right)$ & 80 & 110 & 320 & 326 & 329 & 332 & 335 & 337 & 339 & 342 & 358 \\
\hline Volume $(\mathrm{ml})$ & 0 & 10 & 20 & 30 & 40 & 50 & 60 & 70 & 80 & 90 & 95 \\
\hline
\end{tabular}

\section{Conclusions}

The aim of this study was exploring the potential for biodiesel production from waste vegetable oils in Albania. The interest in the use of WVO consists related to the price, which is considerably lower compared to the fresh unused Vegetable oils. The potential capacity of $6000 \mathrm{t}$ of biodiesel in-country is attractive in the economic aspect, and it might introduce Albania in the world market of WVO. The involvement of governmental stakeholders in that activity by implementing legislation, directives, and recommendations, and implementing schemes on financial support to the system will increase premises for success. Due to the high level of FFA in WVO, transesterification is not directly applied. Initially, the feedstock was treated with an acid catalyst to esterify the FFA. After separation from water, the triglyceride phase further processed through the transesterification process. The primary Used Vegetable Oil by the Restaurants and Fast-Foods is palm oil, due to the competitive price and physic-chemical properties. Production of the biodiesel from Waste vegetable oils is Laboratory scale is a good premise for its implementing of large scale production.

\section{Compliance with ethical standards}

Conflict of interest The author declares that he has no conflict of interest.

\section{References}

1. AMK (2013) Data on licensed subjects with activity in Tirana City. AMK-Agency for Consumer Protection to Tirana Municipality

2. Ali Y, Hanna MA (1994) Alternative diesel fuels from vegetable oils. Bioresour Technol 59:153-163

3. Araujo VKWS, Hamacher S, Scavarda LF (2010) Economic assessment of biodiesel production from waste frying oils. Bioresour Technol 101:4415-4422

4. ASTM D6751 (2003) Standard specification for biodiesel fuel (B100) blend stock for distillate fuels (American Society for Testing and Materials, Philadelphia, Pennsylvania

5. Bannister CD, Chuck CJ, Bounds M, Hawley JG (2011) Oxidative stability of biodiesel fuel. Proc Inst Mech Eng Part D J Automob Eng 225(1):99-114

6. Canakci M (2007) The potential of restaurant waste lipids as biodiesel feedstocks. Bioresour Technol 98:183-190

7. Canakci M, Van Gerpen J (2003) A pilot plant to produce biodiesel from high free fatty acid feedstocks. Trans ASAE 46(4):945-954
8. Canakci M, Van Gerpen J (2001) Biodiesel production from oils and fats with high free fatty acids. Transactions of ASAE 44(6):1429-1436

9. Davis SC, Anderson-Teixeira KJ, DeLucia EH (2009) Lifecycle analysis and the ecology of biofuels. Trends Plant Sci 14(3):140-146

10. Dorado M, Cruz F, Palomar J, Lopez F (2006) An approach to the economics of two vegetable oil-based biofuels in Spain. Renew Energy 31:1231-1237

11. EASAC (2012) The current status of biofuels in the European Union, their environmental impact, and prospects. http:// www.easac.eu. Accessed 20 April 2014

12. EN 14124 (2003) Automotive fuels-fatty acid methyl esters (FAME) for diesel engines-requirements and test methods

13. Encinar JM, Sanchez N, Martinez G, Garcia L (2011) Study of biodiesel production from animal fats with high free fatty acid content. Bioresour Technol 102:10907-10914

14. EPA (2002) A comprehensive analysis of biodiesel impacts on exhaust emissions

15. Hall KD, Guo J, Dore M, Chow CC (2009) The progressive increase of food waste in America and its environmental impact. PLoS ONE 4(11):e7940. https://doi.org/10.1371/journ al.pone.0007940

16. Hamouda MT, Elsheemy AN, Kamal MM, Hennes GM (2014) Parametric study of using transesterified biodiesel in a diesel engine. Proc Inst Mech Eng Part A J Power Energy 228(6):674687. https://doi.org/10.1177/0957650914534230

17. Hill S (2007) Philadelphia's trap of grease. National Energy Policy versus Urban Realities. Public Works Manag Policy 11:194-203. https://doi.org/10.1177/1087724x06297320

18. IARC (2010) Working group on the evaluation of carcinogenic risks to humans. Household use of solid fuels and high-temperature frying. Lion, France

19. Isidori M, Parrella A (2009) Genotoxicity of aqueous extract from heated cooking oils and its suppression by lactobacilli. Food Sci Technol Int 15:267-273

20. Kapustina V, Havukainen J, Virkki-Hatakka T, Horttanainen M (2014) System analysis of Waste Oil Management in Finland. Waste Manag Res 32(4):297-303

21. Knothe G, Steidley KR (2009) A comparison of used cooking oils: a very heterogeneous feedstock for biodiesel. Bioresour Technol 100:5796-5801

22. Knothe $G$ (2010) History of vegetable oil-base diesel fuels. In: Knothe G, Krahl J, Gerpen JV (eds) The biodiesel handbook, 2nd edn. AOCS Press, Urbana, p 61802

23. Kowalewicz A, Wojtyniak M (2005) Alternative fuels and their application to combustion engines. Proc Inst Mech Eng Part A J Power Energy 219:103-126

24. Lang X, Dalai AK, Bakhshi NN, Reaney MJ, Hertz PB (2001) Preparation and characterization of bio-diesel from various bio-oils. Bioresour Technol 80:53-62

25. Liang S, Xu M, Zhang T (2013) Life cycle assessment of biodiesel production in China. Bioresour Technol 129:72-77

26. Lindhejm C, Pollack A (2003) Impact of biodiesel fuels on air quality and human health: Task 1. Report NREL/SR-540-33794. A blend of as 2 percent biodiesel can improve the lubricity and distributor-type diesel fuel pumps

27. Ma F, Hanna MA (1999) Biodiesel production: a review. Bioresour Technol 70:1-15 
28. Pinto AC, Guarieiro LLN, Rezende MJC, Ribeiro NM, Torres EA, Lopes WA et al (2005) Biodiesel: an Overview. J Braz Chem Soc 16(6B):1313-1330

29. Ruiz-Mendez MV, Marmesat S, Liotta A, Dobarganes MC (2008) Analysis of used frying fats for the production of biodiesel. Grasas Aceites 59(1):45-50

30. To WM, Lau YK, Yeung LL (2007) Emission of carcinogenic components from commercial kitchens in Hong Kong. Indoor Built Environ 16(1):29-37

31. Tomasevic AV, Siler-Marinkovic SS (2003) Methanolysis of used frying oil. Fuel Process Technol 81:1-6

32. Van Gerpen J, Shanks B, Pruszko R, Clements D, Knothe G (2004) Biodiesel production technology. NREL/SR-510-36244. National Renewable Energy Laboratory, Colorado, USA

33. Wiltsee $G$ (1998) Urban waste grease resource assessment NREL/SR-570-26141, Golden CO, National Renewable Energy Laboratory
34. Yusuff AS, Adeniyi OD, Olutoye MA, Akpan UG (2018) Waste frying oil as a feedstock for biodiesel production. In: Zoveidavianpoor M (ed) Petroleum chemicals—recent insight. Pula, Intechopen, pp 5-24

35. Zhang Y, Dube MA, McLean DD, Kates M (2003) Biodiesel production from waste cooking oil: 1. Process design and technological assessment. Bioresour Technol 89:1-16

Publisher's Note Springer Nature remains neutral with regard to jurisdictional claims in published maps and institutional affiliations. 